\title{
PERSPECTIVE ON ISSUES ABOUT MHM AT COMMUNITY LEVEL IN THE STATE OF BIHAR, INDIA
}

\author{
Dr. Tridibesh Tripathy', Dr. Neelam Singh ${ }^{2}$, Ms Anjali Tripathy ${ }^{3}$, Ms Shagun Tripathi ${ }^{4}$ \&s Shweta Singh ${ }^{5}$
}

'Homoeopathic \& Public Health Expert and Subject Expert, Master of Public Health (Community Medicine) Course, Lucknow University, Lucknow.

${ }^{2}$ Chief Functionary, Vatsalya, C-377, Indira Nagar, Lucknow

3Program Coordinator, Water Aid, UP office, Lucknow

4Program Coordinator, Vatsalya, Lucknow

5Former Program Coordinator, Vatsalya, Lucknow

Corresponding Author Email : tridibeshtripathy@gmail.com.

\section{ABSTRACT}

Menstrual Hygiene Management (MHM) is an active component of Adolescent health initiative of the Rashtriya Kishori Swasthya Karyakram (RKSK) of the National Health Mission (NHM) of all the 18 Empowered Action Group states where NHM is operational since the introduction of National Rural Health Mission (NRHM) in 2005 (Gol, 2014). The current study relates to the state of Bihar where the MHM is operational through the NHM. After a year of RKSK, the MHM guidelines of India was developed in 2015 (Gol,2015).MHM is defined as 'women \& adolescent girls are using clean menstrual management materials to absorb or collect blood that can be changed in privacy as often as necessary for the duration of the menstrual period, using soap \& water for washing the body as required \& having access to facilities to dispose of used menstrual management materials (WHO/UNICEF JMP, 2012).Globally, at least 500 million women \& girls lack proper access to menstrual hygiene facilities. Several factors influence difficult experiences with menstruation, including inadequate facilities \& materials, menstrual pain, fear of disclosure \& inadequate knowledge about the menstrual cycle (World Bank, 2018).Women \& girls typically wash \& change menstrual materials at home. They use sanitation facilities that are not safe, clean or private \& frequently lack water or soap that relatively few facilities meet all these criteria. Access to appropriate materials \& the type of material used also varies widely across countries (WHO \& UNICEF, 2019). The global MHM day started in 2014 when the German based NGO WASH united co-ordinated the menstrual hygiene day as the overall global co-ordinator. The global day was decided to be the $28^{\text {th }}$ of May every year as the menstrual cycle is of 28-day duration \& usually lasts for 5 days. That's how it is $28^{\text {th }}$ day of the $5^{\text {th }}$ month of every year (Wikipedia, 2014). Similarly, on these lines, the RKSK program was also launched in India in the year 2014 (Gol, 2014).The objective of the current study was to collect \& aggregate qualitative data through involvement of stakeholders like schools \& community of Gaya, Purnia \& Sitamarhi districts of the state of Bihar to reflect on issues of MHM. The study was a step towards the process of developing 
a roll out map of MHM related issues at the state \& district level.Focus Group Discussions (FGD) were held for community members \& school students for Sitamarhi district where they had come to the district level for the discussions. Similarly, FGDs were conducted at school level \& community level stakeholders of Gaya \& Purnia districts. FGD protocols were used as research tools to conduct FGDs for the participants of the purposively selected schools \& community.

\section{About MHH \& related vocabularies (UNICEF, 2019)}

Menstrual Health \& Hygiene (MHH) encompasses both MHM \& the broader systemic factors that link menstruation with health, well-being, gender equality, education, equity, empowerment \& rights. These symptomatic factors have been summarized by United Nations Educational Scientific \& Cultural Organisation (UNESCO) as accurate \& timely knowledge, available, safe \& affordable materials, informed \& comfortable professionals, referral \& access to health services, sanitation \& washing facilities, positive social norms, safe \& hygienic disposal, advocacy \& policy.

A menstruator is a person who menstruates \& therefore has menstrual health \& hygiene needs. These persons are girls, women, transgender \& non-binary persons.

Menstrual hygiene materials are the products used to catch menstrual flow such as pads, cloths, tampons or cups.

Menstrual supplies are other supportive items needed for MHH such as body, laundry soap, underwear \& pain relief items.

Menstrual facilities are those facilities most associated with a safe \& dignified menstruation such as toilets \& water infrastructure.

Menstrual waste refers to blood \& used \& discarded menstrual absorbents including cloth, disposable sanitary napkins, tampoons \& other substances or materials that girls \& women use to soak up or hold blood during menstruation (MODWS, MHM Alliance India, UNICEF, 2015).

The Menstrual waste is defined as a solid waste \& sanitary waste as per Solid Waste Rules, 2016 (MOEFCC, 2016). 


\section{Introduction}

Hypatia, a philosopher, mathematician, teacher \& inventor of Alexandria, Egypt, who lived from 350-370 Christian Era (CE) to 415 CE threw her used menstrual pad at an admirer in an attempt to get rid of him (Femme International, 2013). This is the first recorded use of sanitary pads in the global history. Commercially, Johnson \& Johnson developed their own version of sanitary pads in 1896 called Listor's Towel or sanitary towels for Ladies (Femme International, 2013).

With passing time, the issue of menstruation got more complex in each nation along with India where the social, cultural \& religious factors influence the issue. MHM is a three-word issue. The first two words relate to the individual, household \& social institutions around which the hygiene factors revolve around. The third word is management that includes the manufacturing of pads, supply chain of pads \& the disposal method of the used sanitary pads.

The above-mentioned paragraph is substantiated by a study in 2018. The study elicited that menstruation \& menstrual practices still face many social, cultural, religious restrictions which are a big barrier in the path of MHM. Awareness is to be created to promote use of reusable sanitary products or the natural sanitary products made from materials like Banana \& Bamboo fibres, Sea sponges \& Water Hyacinth (Kaur $R$ et.al, 2018). Another study mentions that due to cultural norms \& stigmas, menstruating women are not allowed to use water \& impure (Water Aid, 2009).
Restrictions on movement \& normal life are forced upon menstruators globally (Jewitt \& Ryley, 2014). Nightingale in a study reports that these restrictions range from living in cow-sheds to not entering kitchens \& not being allowed to wash their hair (Nightingale, 2011). These restrictions even go to the extent of inhumane treatment thus abusing \& violating human rights of menstruators (WSSCC, 2013).

Basically, the issue of MHM has an integral intimate component as the menstruator is an individual. There is need for a greater scrutiny of the intimate as a social issue \& its regulation by explicit \& implicit power relations (Tilley et.al, 2013:305). As health concerns rarely stimulate demand for sanitation facilities, there is a need to prioritize user-based preferences for comfort, convenience, privacy, safety, dignity \& accessibility of existing gaps between official \& user-based conceptions of improved sanitation technologies are to be bridged (Jenkins \& Sugden, 2006: Peal et.al, 2010). This is the premise on which the current study is based as the administrators as well as the community members have participated in giving their feedback towards MHM roll out in the state of Bihar.

Another study cites that the inclusion of additional functions \& monitoring mechanisms to address gendered sanitation priorities could help to improve MHM provision \& address broader concerns about WASH related Gender Based Violence (Jewitt S \& Ryley H, 2015). The issue of gender has been dealt in 
detail through the feedback of the various stakeholders on the issue of MHM.

Studies have been done to understand the effective strategies to deal with the above-mentioned issues. A study done in 2014 mentions that to roll out MHM related initiatives, the most effective strategies include engaging community members, training of key stakeholders \& to cultivate peer leaders. It also mentions that the state of Tamil Nadu is the first to recognize MHM as an issue to be addressed through its sanitation policies \& programs. It also mentions the role of media while mentioning that Indian media reports on MHM actively (Dasra, 2014). The study by Water Aid also indicated that key areas on MHM should be relationship between menarche \& school drop-out, relationship between MHM \& other health outcomes, to increase awareness of MHM among household decision makers including husbands, fathers \& in-laws (Water Aid, 2009).

One of the resource materials to help girls \& women understand menstruation is the menstrual wheel as an information tool. The menstrual wheel helps answer the 'how' of the menstrual cycle, enabling participants to visualize the monthly cycle. It helps answer questions on pain, blood, tissue or uterine wall discharge \& provides a link to talking about conception (WSSCC, 2013). Another Information, Education \& Communication (IEC) material on MHM is the "as we grow up' flip book on MHM. Images in the flip book allow participants to visualize the changes in the body from childhood to adulthood. The book eases the participants into the topic of menstruation (WSSCC, 2013).

For the use of the public health system of the states, a Training of Trainers (ToT) manual has also been developed to train all the institutional \& outreach health workers so that MHM is rolled out effectively at all the state levels that includes the state of Bihar as well (WSSCC, 2013).

The figure below shows how MHM is cross sectoral involving education, reproductive health, gender \& Water Sanitation \& Hygiene (WASH) to reach all girls. There are four Sustainable Development Goals \& two goals of Global Partnership for Education strategy (GPE) that are related to MHM. Hygiene \& specific needs of women of MHM is related to SDG 6, gender sensitive infrastructure of MHM is related to SDG 4, reproductive health of MHM is related to SDG 3, ending all forms of discrimination \& empower all girls of MHM is related to SDG 5 (UN,2015). Similarly, the two goals of GPES as mentioned in the figure are related to addressing the components of MHM (GPE, 2020). India is grouped under Central Asia \& Southern Asia under regional groupings for SDGs which shows that the region has very high inequalities for WASH related services even after the roll out of the Millenium Development Goals (JMP, 2015: WHO, 2017: UNICEF \& WHO, 2019) 
Figure 1

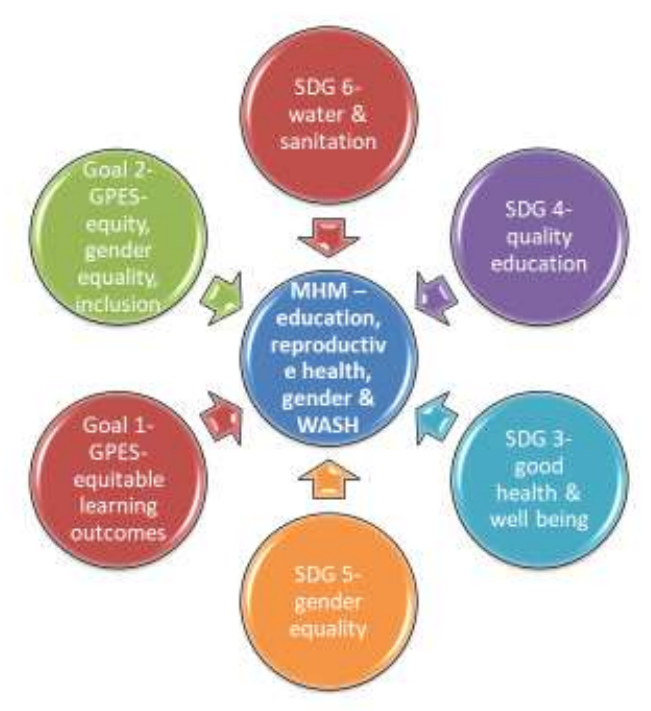

\section{Current situation of MHM in India}

One of the key stakeholders in this article is the selected Government schools in the three districts. The latest report of the Annual Status of Education Report (ASER) i.e. the $13^{\text {th }}$ report mentions that $22.8 \%$ of rural schools surveyed have usable toilets $\& 11.5 \%$ of rural schools have no separate toilets for girls. While some schools had separate toilet for girls, $10.5 \%$ of these were locked \& $11.7 \%$ were locked \& unusable (ASER, 2019).

A direct link exists between menstruation \& school drop outs in girls studying in higher primary \& secondary education schools (Muralidharan et.al, 2015: Sommer et.al, 2016). Another study mentions that not only menstruation but also puberty in girls also leads to school drop-out (Sommer, 2010). The effects of all these lead to girls lagging behind boys in higher education, forced to marry early, menstruation forces them to stay at home leading to further school drop outs (TEN, 2007: Jewitt \& Ryley, 2014). Thereafter, the whole process leads to unequal opportunities among boys \& girls (TEN, 2007). This is the basic reason for the existing inequalities among boys \& girls in India.

Across the nation, women \& girls face three types of toilet insecurities. The first one is the material reality that they do not have access to a toilet. The second is even if they have access to a public toilet, the toilet is unusable (e.g. filthy), unsafe (e.g. insufficient lighting). The third is that they accept the risk of going for 
open defecation (Reilly O K, 2016). All these insecurities are a big obstacle for MHM in India.

The context of rural area \& MHM has been dealt through a study in rural Odisha, a state in India. The study mentions that at different stages of life in rural areas, India have a multitude of unaddressed urination, defecation \& menstruation concerns. This means in addition to the toilet insecurity, the sanitation insecurity concerns is also critical \& these concerns falls in to four domains. These are socio-cultural context, physical environment, social environment \& personal constraints. These are also influenced by season, time of day, life stage, toilet ownership which were linked with an array of adaptations (i.e. suppression, withholding food \&water) \& consequences (i.e. scolding, shame, fear) (Caruso B A et.al, 2018). Thus, it is seen that the issue of MHM operates in a socio-cultural complex that are contextual to our life stages.

It is significant to note here that the state of Odisha has an annual festival known as 'Raja' festival. The term Raja comes from the word Rajaswala which means a menstruating woman. It is a 4-day festival that is celebrated in the mid-June $\left(14^{\text {th }}\right.$, $15^{\text {th }}, 16^{\text {th }}, 17^{\text {th }}$ usually) every year. It signifies that mother earth menstruates just like women do \& during this period the menstruation of mother earth is celebrated. Menstruation symbolizes fertility \& creativity. The traditional knowledge on agriculture supports the belief that during this period, the earth is most fertile \& it is the best time for germination of seeds. Hence, Raja festival marks the onset of sowing season after a long dry spell. On the $4^{\text {th }}$ day of the 4-day festival, mother earth is given a ceremonial bath (Panda R, Oxfam India, 2020). Hence, it is seen how culturally menstruation is embedded in the agrarian society.

The Water Supply \& Sanitation Collaborative Council mentions that among 747 girls across India, $70 \%$ had no idea about menstruation at the onset of menarche (WSSCC, 2013). The 2005-2006 study of Indian Council of Medical Research (ICMR) mentions that $70 \%$ of mothers consider menstruation dirty \& polluting with many teachers \& Front-Line Health Workers (FLW) echoing this sentiment thus perpetuating a culture of silence, shame \& misinformation to the next generation (ICMR, 2005-06).

Another study in India mentions four important aspects of MHM. The first aspect informs that $88 \%$ menstruating women use old fabric, rags or sand. The second aspect mentions that Reproductive Tract Infections (RTI) are $70 \%$ more common among women who use unhygienic materials. The third aspect deals with schools where it says that girls are typically absent for $20 \%$ of school year due to menstruation, the second reason after household work. The last deals with Self Help Groups (SHG) where it stresses that despite the growing number of local SHGs producing sanitary pads, they often face limited economic viability (A C Nielsen \& Plan India, 2010).

The large-scale sample survey of India mentions that 130 million of India's households lack toilets, leaving particularly women \& girls with many challenges to manage their menstruation 
in privacy while maintaining hygiene (NSSO, 2012). The issue of MHM \& all its related modalities are discussed in a nut shell in the 2016 Global MHM day celebration document for India (MHM day, India fact sheet, 2016).

\section{MHM in India as per NFHS 4}

The AC Nielsen study done in 2010 \& mentioned below is the first large scale study on MHM in India. The next large- scale study that included MHM is the National Family Health Survey (NFHS) $4^{\text {th }}$ round. As per NFHS 4, at the country level, use of cloth \& other materials by MHM users are categorised under using unhygienic methods. Similarly, the hygienic methods are like locally prepared sanitary napkins, other sanitary napkins \& tampoons. The table below gives both these hygienic \& unhygienic methods with the names of the states \& the percentage of users in these states under these two categories separately.

Table 1 - States \& the users of Hygienic \& Unhygienic methods of MHM (Source-NFHS 4, 2015-16)

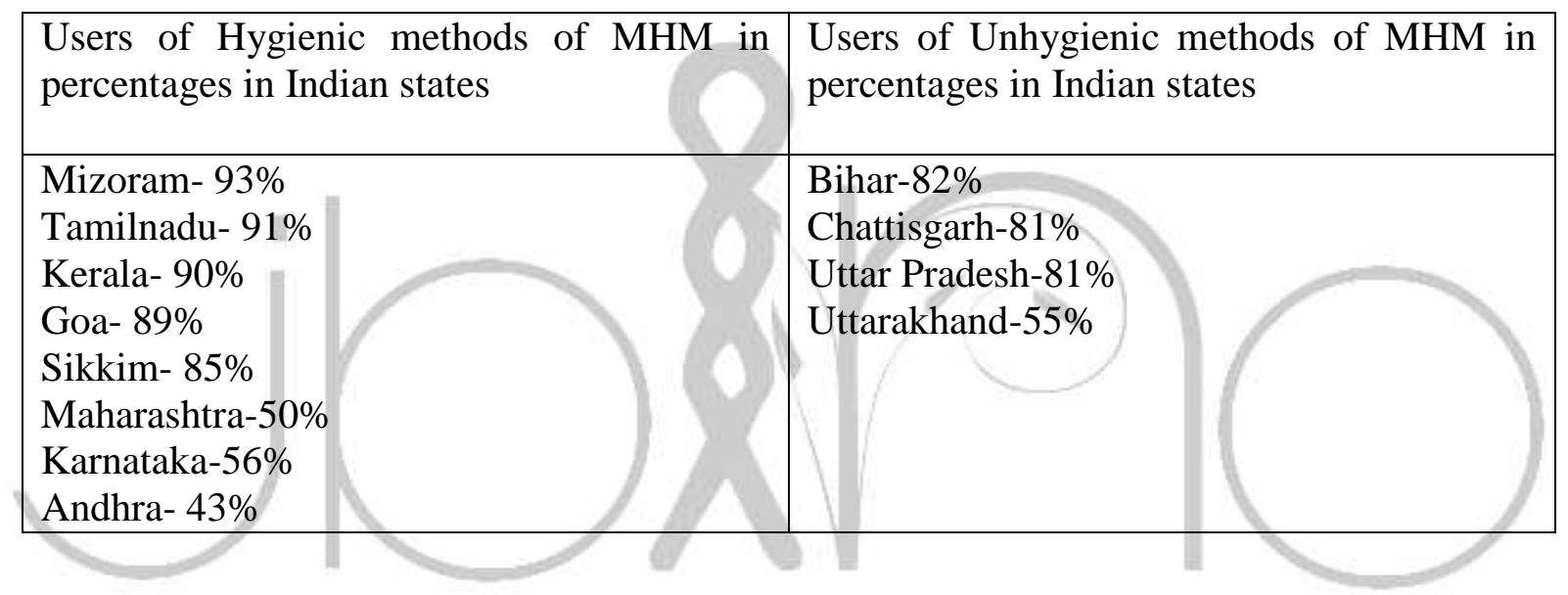

It is seen that largely the smaller states have more hygienic users than the larger states. Further analysis in the survey reflects that among the hygienic users, $42 \%$ use sanitary napkins, $16 \%$ use locally prepared napkins. Among those surveyed, $48 \%$ in rural area use sanitary napkins \& $78 \%$ of those surveyed in urban areas use sanitary napkins.

The survey also establishes a link between education \& wealth for the use of hygienic protection. The survey mentions that women with 12+ years of schooling use 4 times more than non-schooling. Women with highest wealth quintile use 4 times more than the lowest wealth quintile.

The survey mentions 'Jaunsar Bawar' region of Uttarakhand state filled with cultural taboos. This issue has been dealt in detail in this article. Regarding opinion of users, the survey tells us that low cost pads are not given regularly \& young girls are shy to ask for pads. It suggests that a local depo holder can be set up at the community level to keep pads. This suggestion was given in the survey report written in 2015-16 \& as a result of that, the Suvidha pads \& the modalities to upscale 
the use of pads was strategized by the Governments as mentioned in this article.

It also cites that eight states account for $70 \%$ of cloth users in the country. Regarding number of users, it is seen that the state of Bihar has 6.5 million users whereas the state of Uttar Pradesh has 15.6 million users. The report also mentions that only $55 \%$ of young girls in the nation think the menstrual cycle as natural while only $23 \%$ knew that the blood comes out of the uterus.

However, NFHS 4 is limited to adolescent girls and young women in the age group of 15-24 years of age and it does not mention about the frequency of use (PSI, 2018).

\section{MHM in Bihar}

A study done in Vaishali \& Nalanda districts on knowledge, attitude, practices \& norms related to adolescent girls revealed that $83 \%$ of girls were completely unprepared for menarche. It showed their first experience of menstruation is of shame, fear, horror, agony or sin. Out of all the girls surveyed, $96 \%$ of girls use cloth that is not washed properly \& not dried in sunlight resulting in repeated infections. Further, $59 \%$ of girls missed their schools on account of menstruation (IDF, UNICEF, 2013). As mentioned above, as per NFHS 4, at the country level, $62 \%$ of young women still use cloth for MHM where as $82 \%$ in Bihar use cloth and all these users are categorised under using unhygienic methods. NFHS 4 further states that Bihar is among the eight states that account for $70 \%$ cloth users and there are 6.5 million users in the state. The mean for these eight states was $43.5 \%$ with Bihar being the worst at $31 \%$.

Keeping this background in mind, to roll out MHM in the state of Bihar, the article looks at the efforts of the stakeholders such as Civil Society Organizations (CSO), corporates and the Government of Bihar. In Bihar, the active CSOs like Healing Field and WaterAid are engaged in MHM related activities besides various public departments like health, education and Panchayatiraj. It is significant to note that Flagship programs like Mukyamantri Kanya Utthan Yojana are being implemented in Bihar since 2014 (Down to earth, GoBihar, 2015). The program involves conditional cash benefit transfer of ₹ 300 directly in to the account of each of the school going adolescent girls per year to enable them to buy sanitary pads through the Direct Benefit Transfer (DBT) mechanism. The condition to get the benefit for the girls is that they need to have $75 \%$ attendance in the schools in the current year to avail the benefit. The adolescent cell of the Government of Bihar operates the yojana. The Government of Bihar spends about ₹ 80 crores per year to roll out the yojana (Down to earth, GoBihar, 2015).

Following this, the Government of Bihar involved all the stakeholders \& in collaboration with UNICEF developed the MHM guidelines for the state in 2019 on the lines of the MHM guidelines of Gol of 2015 (Gol, MHM, 2015: Go Bihar, MHM Guidelines, 2019). A study done in Assam on sanitation also can be related to Bihar as both the states face flooding every year. It talks of sanitation stacking (simultaneous use of a range of sanitation systems) also occurs due to a preference 
for open defaecation coupled with high demand for existing latrines, especially during seasonal flooding (Jewitt $S$ et.al, 2018).

\section{Research Methodology}

The sampling technique used in the study is 'Purposive' sampling technique. There are five stages of sampling used in the study. The first stage was to select 13 districts out of 38 districts using the aspirational district list of NITI Ayog for the state of Bihar. In the second stage, three districts of Bihar were selected purposefully from the list of aspirational districts of Bihar as per the list of National Institution for Transforming India (NITI) \& these districts were Gaya, Purnia \& Sitamarhi. There are 13 aspirational districts in the state of Bihar \& out of 13,3 districts were chosen for the study (Gol, Ministry of Planning, NITI Ayog, 2018).

The third stage of sampling was selecting the blocks. Here also, depending on the feasibility \& availability of man power, one block was purposively selected in Gaya district \& two blocks were selected in Purnia district. At Sitamarhi, the stakeholders were requested to come to the district level as per the modality provided by the district administration.
The fourth stage of sampling was selecting the community in these blocks. Depending on the feasibility \& manpower, purposively the villages in these blocks were selected.

The fifth stage of sampling was to choose the community members. Since the issue was on MHM, women in the reproductive age group \& above were purposively selected as the respondents.

Participatory process was followed with the community members using metacards that were developed on the subject of menstruation. The details are given in the sub-section given below where the contents of the meta-cards along with the steps followed with the participants are described.

Focus Group Discussions (FGD) were held to elicit information from the women in the groups. Through these FGDs, qualitative data on MHM were elicited from the participants. The following table gives the name of districts, the selected blocks \& the number of participants in the discussions.

Table 1

\begin{tabular}{|l|l|l|}
\hline Names of the districts & $\begin{array}{l}\text { Names of the blocks } \\
\text { selected purposively }\end{array}$ & $\begin{array}{l}\text { Number of participants at } \\
\text { school \& community } \\
\text { selected purposively }\end{array}$ \\
\hline Gaya & Sherghati & $\begin{array}{l}\text { Group meeting with 20 } \\
\text { females in the reproductive } \\
\text { ag group \& 8 in the } \\
\text { climacteric period }\end{array}$ \\
\hline Purnia & Kasba & $\begin{array}{l}\text { Group meeting with 20 } \\
\text { females in reproductive age }\end{array}$ \\
\hline
\end{tabular}




\begin{tabular}{|l|l|l|}
\hline & & $\& 5$ in climacteric period \\
\hline Sitamarhi & District level & $\begin{array}{l}5 \text { community members (3 } \\
\text { males \& 2 females) } \\
\text { associated with Jeevika } \\
\text { group. }\end{array}$ \\
\hline
\end{tabular}

\section{Research Tool}

The research tool used for the study were the two Focus Group Discussions (FGD) protocols where the FGD protocol for the community level was used in the discussion. The flow of the tool was such that it covered seven aspects of MHM. The seven aspects were the myths \& misconceptions, use of sanitary pads \& services, availability \& feasibility of sanitary pads, about the Mukhya Mantri Kanya Utthan Yojana of Bihar government, Male involvement in MHM \& disposal of used menstrual material.

\section{Participatory Process Adopted with the Groups}

There are five headings under which the meta cards were grouped \& the contents of the cards along with the dialogue points with the group used by the facilitators is given in detail. Ms. Shagun \& Ms. Shweta who are the coauthors of this article were the facilitators. Each of the steps of the participatory process is given in separate boxes.

This session helped the participants to learn about the problem and how they could address all these issues.

\section{Box 1- Ice Breaking}

The facilitators started with a question to the group for initiating the discussions. The question was whether they have heard about MHM or not. All the participants shared their experiences when they had their menarche. The next session was on the myths and misconceptions.

\section{Box 2- Myths and Misconceptions}

\footnotetext{
The facilitators used 4 meta cards to initiate this session. The meta cards were about four behaviours. These were behaviours during the MC periods. The meta cards were shown to the participants.

Whether you can

Bathe or not? Play or not? Cook or not? Eat together or not?

Following this discussion, the participants also wrote their myths on cards given to them and pasted the cards on the chart for reflecting at the larger group level. The next session was on hygiene behaviours during MC days.
} 


\section{Box 3- Hygiene behaviours during MC days}

The facilitators asked about the behaviours to the participants and showed the related meta cards thereafter to the participants asking them if they follow these behaviours or not?

There were 3 meta cards on these behaviours. These were

Whether they

Dry the cloth in sun? Drying the inner garments in sun? Hand wash after cleaning or

touching or handling pads?

\section{Box 4- Disposal}

There were 6 meta cards related to the disposal that included both good and bad methods of disposal. The cards had the following methods of disposal.

Throwing the used pads in water bodies

Throwing in open space

Burying the pads in a pit

Street dogs carrying the pads in their mouth and wander about

Throw the pads in garbage

Burn the used pads

Through this exercise the participants knew about the right and wrong methods of disposal.

The last session was on the discomforts during MC days.

\section{Box 5- Health problems during MC}

The facilitators had 4 questions for the participants in this session. These were

Pain in lower abdomen and back

Headache and colic

Chest pain and heaviness

Clots during bleeding

To this, the participants added two more questions. These were

Eating rice and sweet increases discomfort

Vomiting and nausea during MC days

\section{Data Analysis}

As already mentioned above in the section on research tool, there were seven aspects of MHM on which the group discussions were held \& qualitative data were collected through the response of the participants on these components of MHM. The data was categorized into district wise and group wise. Based upon the responses, sub areas were decided on MHM and these responses were clubbed under these subareas that are related to issues of MHM. The subareas under which the qualitative responses are clubbed are 13 areas in total. These are myths \& misconceptions, menarche, local names of menarche, use of menstrual materials \& practices, support of family members, Knowledge on menstruation, seeking care, health problems during menstrual 
cycle, effects of poor MHM, availability \& feasibility of materials, disposal of used menstrual materials, Mukhya Mantri Kanya Uttthan Yojana \& suggestions of the groups. The categorization along with the number of respondents for the responses are given in the tables mentioned below. Summary of each of the table is given below each of the table that reflects the qualitative data elicited from the group.

The qualitative data captures the verbatims, colloquial language \& the exact responses as given by the respondents. All these responses are linked to the academic studies mentioned in this article through the issues of MHM in the community where the women are an active component of the families in the community.

\section{Reflections from the group at Sitamarhi district}

The group comprised of 5 members where there were 2 females \& 3 male members who were associated with Jeevika group, the CSO that works with the Rural Development (RD) department of Government of Bihar on various issues including MHM. It acts as an extension of the department of RD in the state of Bihar. The facilitators of the group discussions were Ms. Shweta Singh and Ms. Shagun Tripathi (co-authors of the current article) of Vatsalya, the consulting NGO on MHM on behalf of UNICEF, Bihar office hired to do the consultation process at the three districts selected for the study.

Participatory processes were adopted to elicit feedback from the group where chart paper and meta cards on MHM were used as tools for the participatory process. The details are given in the section on research tool. The first aspect dealt during the process was on the dos and do-nots that the community adheres to during the menstrual cycle days. The process also brought out life experiences by the women. The table below gives the details of the group discussions.

Table $2(\mathrm{~N}=5)$ - Sitamarhi district

\begin{tabular}{|l|l|l|}
\hline Thematic area of MHM & Number of respondents & Qualitative data \\
\hline Myths \& Misconceptions & $\begin{array}{l}5 \text { members (2 females \& } 3 \\
\text { males) }\end{array}$ & $\begin{array}{l}\text { No visit to kitchen, no } \\
\text { meeting with males. } \\
\text { Not to touch pickles, not to } \\
\text { go to temples, use and touch } \\
\text { less water because body is } \\
\text { hot and if we put water, it } \\
\text { squeezes the uterus and it } \\
\text { leads to difficulty in child } \\
\text { birth, asked to eat less and } \\
\text { no significant help is } \\
\text { extended. } \\
\text { The general advice is to }\end{array}$ \\
\hline
\end{tabular}




\begin{tabular}{|c|c|c|}
\hline II & & $\begin{array}{l}\text { avoid all sour food items. } \\
\text { On burning the used sanitary } \\
\text { pads/cloth, the lady might } \\
\text { become infertile. } \\
\text { If the used pads are soaked } \\
\text { in lochia and if someone } \\
\text { walks over such discarded } \\
\text { pads, it leads to infertility in } \\
\text { the said women. } \\
\text { Generally menstrual blood is } \\
\text { considered dirty. } \\
\text { MC is considered as a } \\
\text { flower that leads to fruits } \\
\text { synonymous with fertility. } \\
\text { Some of the other practices } \\
\text { related to MHM are not to } \\
\text { eat together, not to cook } \\
\text { together, not to eat milk, egg } \\
\text { as these are considered to be } \\
\text { warm foods for the body, no } \\
\text { curds as it is sour to the } \\
\text { body. } \\
\text { The myths and } \\
\text { misconceptions on MHM } \\
\text { are too deeply grounded as } \\
\text { there is a religious } \\
\text { connotation to the issues. }\end{array}$ \\
\hline Menarche & 10 & $\begin{array}{l}\text { When they had the first MC, } \\
\text { they started crying and } \\
\text { seeing them others also cried } \\
\text { as it was considered to be a } \\
\text { disease and they felt } \\
\text { emotional. }\end{array}$ \\
\hline Local names of menarche & 10 & $\begin{array}{l}\text { Some of the anecdotes used } \\
\text { by the community to } \\
\text { describe the menstrual cycle } \\
\text { are 'chuagaya', 'Lalji a } \\
\text { gaye', 'Mehman a Gaye', } \\
\text { 'Bal dhone wale a gaye'. }\end{array}$ \\
\hline $\begin{array}{l}\text { Use of Menstrual Materials } \\
\& \text { practices }\end{array}$ & 2 & $\begin{array}{l}\text { No open drying of cloths, } \\
\text { hands not to be washed }\end{array}$ \\
\hline
\end{tabular}




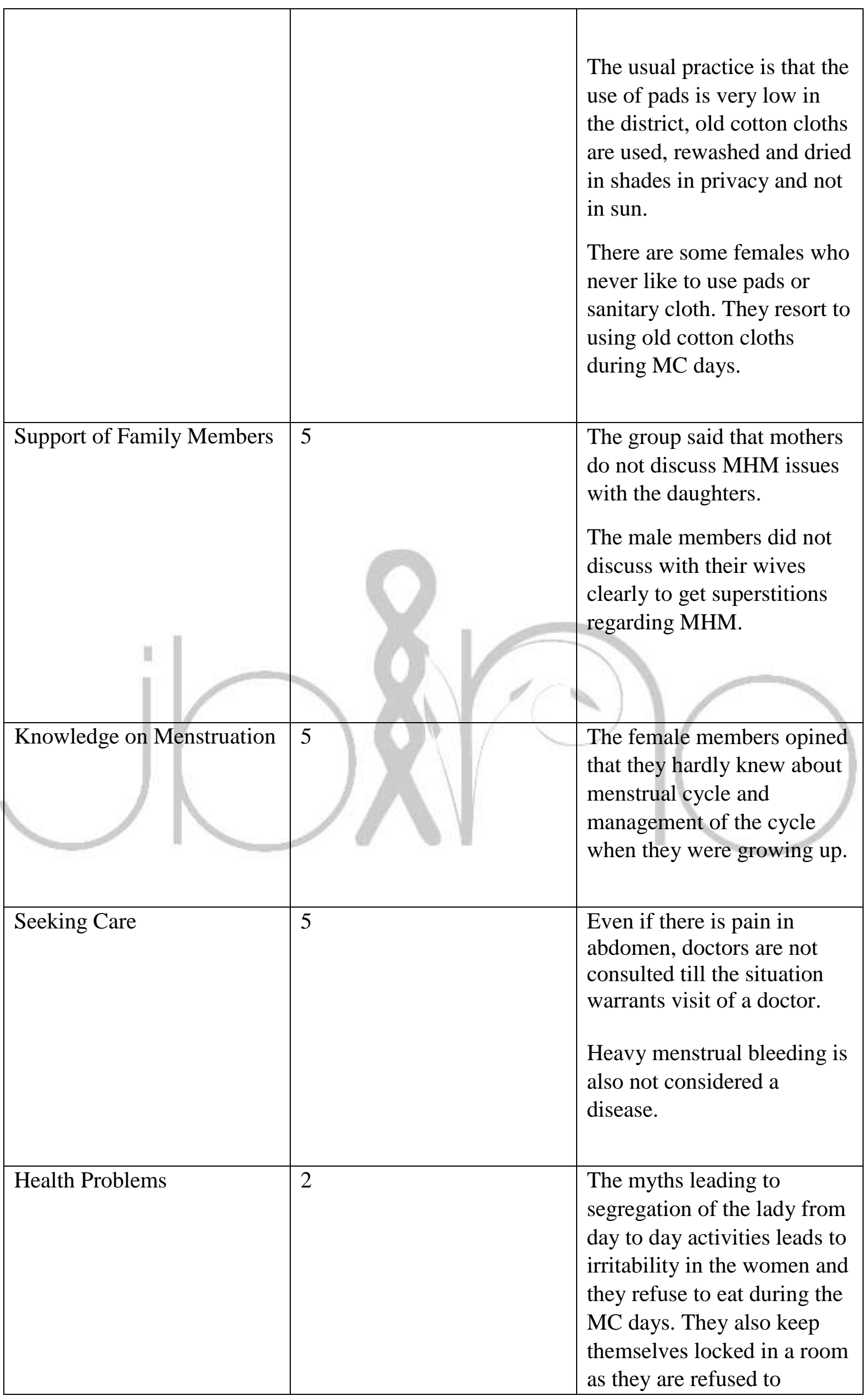




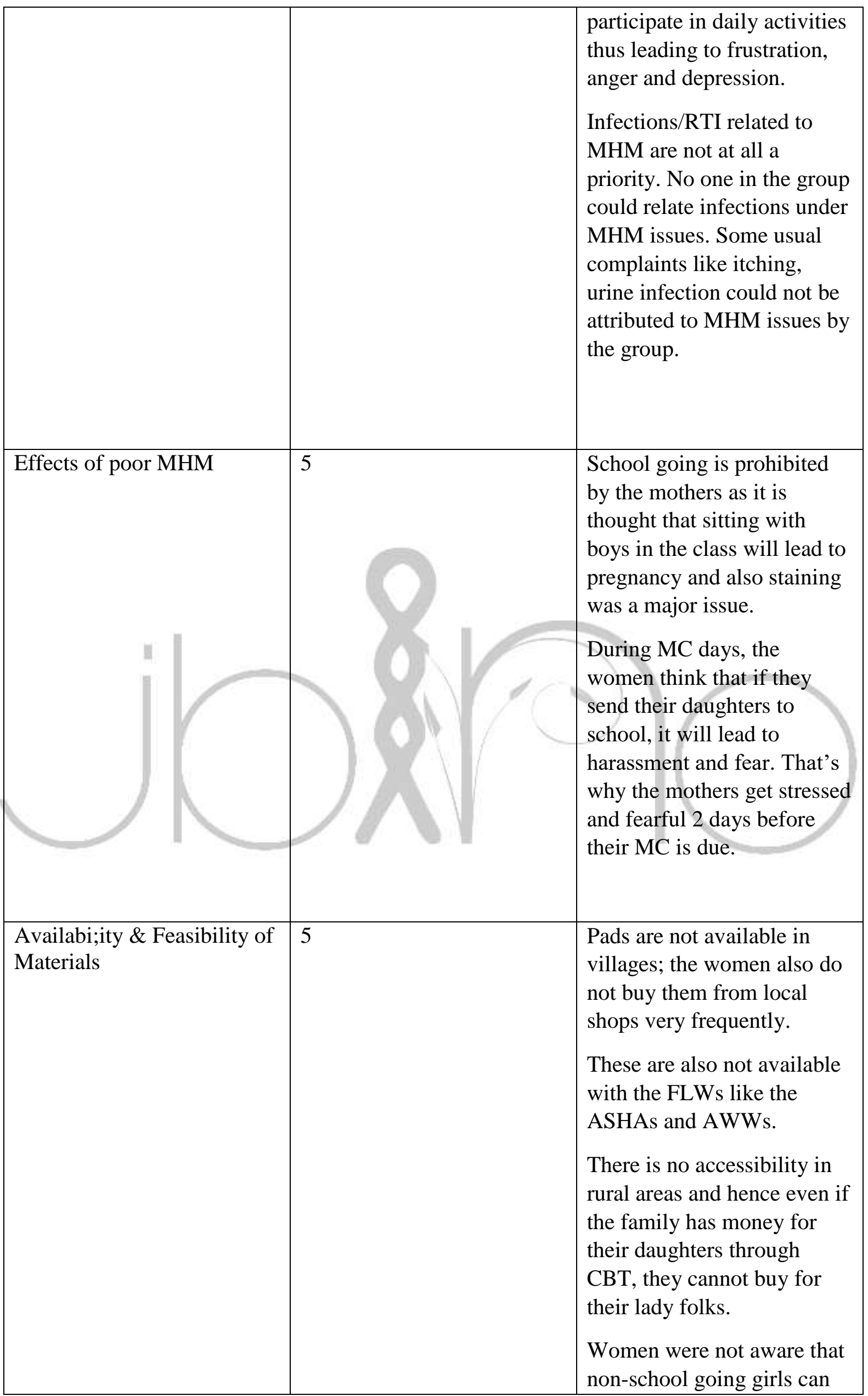




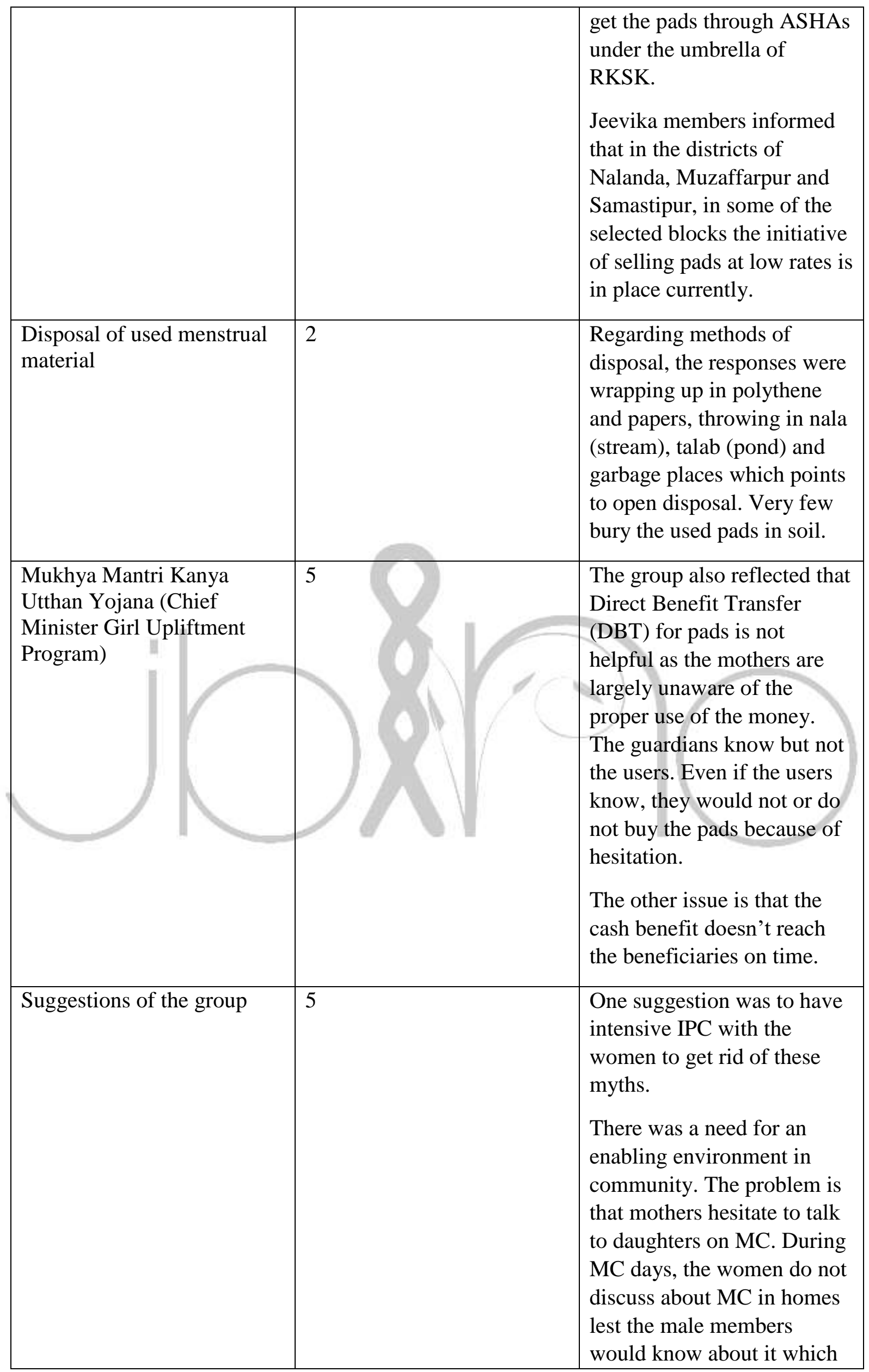




\begin{tabular}{|l|l|}
\hline & $\begin{array}{l}\text { will further embarrass the } \\
\text { women. } \\
\text { One way can be to put up } \\
\text { stalls for selling pads in } \\
\text { central places in community } \\
\text { by agencies where the } \\
\text { community members only } \\
\text { provide a space and } \\
\text { facilitate the process. } \\
\text { Stalls in markets can be the } \\
\text { vehicles to promote the use } \\
\text { of sanitary pads. }\end{array}$ \\
\hline
\end{tabular}

\section{Reflection of the group at Gaya district}

\section{Table 3- Gaya district}

The details of community level discussion with women of Village Nakrupa, Sherghati, Gaya district is given below. There were 20 females in 15-49 years age group and 8 women in climacteric period during the group discussion. All of them were SHG members of Jeevika. The block coordinator of Jeevika had organized the meeting. The reflections of the group on MHM is given below under separate headings. The reflections are given below in separate headings as per table 2 .

$(\mathrm{N}=28)$

\begin{tabular}{|l|l|l|}
\hline Thematic area of MHM & Number of participants & Qualitative data \\
\hline Myths \& Misconceptions & 20 & $\begin{array}{l}\text { Ganda khoon comes out of } \\
\text { the body and it is essential } \\
\text { for child birth. } \\
\text { They consider burning the } \\
\text { pads as a wrong method of } \\
\text { disposal as they consider } \\
\text { blood was from their own } \\
\text { body and burning the used } \\
\text { pads will lead to sterility. }\end{array}$ \\
& $\begin{array}{l}\text { Religious activities are not } \\
\text { done during the MC days } \\
\text { and they do not prepare food } \\
\text { also. } \\
\end{array}$ & $\begin{array}{l}\text { They are asked not to touch } \\
\text { sindoor, not to take tea, not } \\
\text { to eat papaya, cold food as it } \\
\text { will lead to swelling as they } \\
\text { think so. }\end{array}$ \\
& If the water used for bathing \\
&
\end{tabular}




\begin{tabular}{|c|c|c|}
\hline & & $\begin{array}{l}\text { is touched or crossed by } \\
\text { some female/girl, it will lead } \\
\text { to colic, cramps. }\end{array}$ \\
\hline Menarche & 20 & $\begin{array}{l}\text { They feared and were told } \\
\text { by their mother who gave } \\
\text { her cloth, asked to keep it } \\
\text { secret and were told that the } \\
\text { bleeding will come every } \\
\text { month. } \\
\text { Feared to talk to any male } \\
\text { member. } \\
\text { As mothers they tell } \\
\text { daughters to use cloth and } \\
\text { even now, they fear that } \\
\text { bleeding will be more. } \\
\text { Tell daughters not to be } \\
\text { shameful at home. } \\
\text { As teenagers they all felt } \\
\text { irritated and frustrated as } \\
\text { they learnt that the process } \\
\text { will be every month. } \\
\text { All women agreed that their } \\
\text { young daughters should } \\
\text { know about MC beforehand. }\end{array}$ \\
\hline $\begin{array}{l}\text { Use of menstrual materials } \\
\& \text { practices }\end{array}$ & & $\begin{array}{l}\text { Most of the women } \\
\text { informed that they use cloth } \\
\text { They tell their daughters to } \\
\text { use cloth according to need } \\
\text { and pads for } 12 \text { hours as } \\
\text { claimed by 'Stayfree' brand } \\
\text { in their promotion. } \\
\text { No woman in the group } \\
\text { prepares for the cloth to be } \\
\text { used and the clothes are } \\
\text { used randomly. They use } \\
\text { cloth kept in almirah and } \\
\text { they use pads at times when } \\
\text { bleeding is more. } \\
\text { None of them had talked to } \\
\text { their daughters about } \\
\text { Menstrual Cycle. }\end{array}$ \\
\hline Disposal of used menstrual & 20 & The women agreed that \\
\hline
\end{tabular}




\begin{tabular}{|c|c|c|}
\hline materials & & $\begin{array}{l}\text { burning is not the right } \\
\text { method of disposal and they } \\
\text { believed if they burn it will } \\
\text { lead to sterility. They also } \\
\text { believed that burning will } \\
\text { lead to air pollution. } \\
\text { They dispose the cloth in the } \\
\text { garbage and ponds. } \\
\text { Used pads are also thrown in } \\
\text { the garbage and ponds. } \\
\text { They also bury the pads. }\end{array}$ \\
\hline Effects of poor MHM & 20 & $\begin{array}{l}\text { The women informed that } \\
\text { there is no facility in } \\
\text { common places to deal with } \\
\text { MHM and they do not go } \\
\text { out for } 2 \text { days if MC starts. } \\
\text { If the MC starts while at } \\
\text { work, then they leave work. } \\
\text { They complained of } \\
\text { abdominal pain. }\end{array}$ \\
\hline $\begin{array}{l}\text { Availability \& feasibility of } \\
\text { menstrual materials }\end{array}$ & & $\begin{array}{l}\text { Two years ago, in } 16 \text { and } 17, \\
\text { they got pads from ASHAs } \\
\text { for Rs } 20 /- \text { for a pack of } 7 \\
\text { pads when the scheme was } \\
\text { in place. } \\
\text { Most of them do not involve } \\
\text { any males to buy pads for } \\
\text { them and only some HHs } \\
\text { do. } \\
\text { They do not prepare for any } \\
\text { menstrual cloth to be used } \\
\text { and use whatever is } \\
\text { available. }\end{array}$ \\
\hline $\begin{array}{l}\text { Mukhya Mantri Kanya } \\
\text { Utthan Yojana (Chief } \\
\text { Minister Girl Upliftment } \\
\text { Program) }\end{array}$ & 20 & $\begin{array}{l}\text { The mothers in the group } \\
\text { had no idea about the funds } \\
\text { that are transferred in the } \\
\text { account for buying pads for } \\
\text { their school going daughters. }\end{array}$ \\
\hline $\begin{array}{l}\text { Role of Government, CSOs } \\
\text { like Jeevika }\end{array}$ & 28 & $\begin{array}{l}\text { The group is keen to use } \\
\text { home-made pads and are } \\
\text { keen to make the pads as }\end{array}$ \\
\hline
\end{tabular}




\begin{tabular}{|c|c|c|}
\hline & & $\begin{array}{l}\text { well using social marketing } \\
\text { approach. } \\
\text { The members are also } \\
\text { interested to buy the pads } \\
\text { from any local source. They } \\
\text { are also keen to sell. } \\
\text { There has been no } \\
\text { discussion on MHM in the } \\
\text { meetings of the members of } \\
\text { Jeevika group in the last } 6 \\
\text { months. }\end{array}$ \\
\hline Knowledge on menstruation & 6 & $\begin{array}{l}\text { Menstruation happens to } \\
\text { give birth. } \\
\text { They replied that MC } \\
\text { happens for 'Suddhikaran' } \\
\text { purposes of the body. }\end{array}$ \\
\hline Seeking care & 20 & $\begin{array}{l}\text { One woman replied that she } \\
\text { gets severe pain in abdomen } \\
\text { during her MC days and she } \\
\text { has not talked to any family } \\
\text { member or has consulted } \\
\text { any doctor yet. }\end{array}$ \\
\hline Health problems & 20 & $\begin{array}{l}\text { Some woman had secondary } \\
\text { amenorrhoea since last } 4 \\
\text { months but has told no one } \\
\text { about it yet. } \\
\text { Most of the woman } \\
\text { complained of burning } \\
\text { sensation when she used } \\
\text { pads/cloth for long hours. } \\
\text { Another few complained of } \\
\text { rashes on the thighs, foul } \\
\text { smell and burning sensation } \\
\text { during periods. }\end{array}$ \\
\hline Support of family members & 20 & $\begin{array}{l}\text { Very few women replied } \\
\text { that she informed her mother } \\
\text { about her menarche and she } \\
\text { was encouraged by the } \\
\text { mother to talk to her. } \\
\text { They also tell their daughter } \\
\text { that this is a monthly } \\
\text { phenomenon. }\end{array}$ \\
\hline
\end{tabular}




\begin{tabular}{|l|l|}
\hline & $\begin{array}{l}\text { Few women had talked } \\
\text { about MHM to her husband } \\
\text { or any other male member. } \\
\text { in the school. }\end{array}$ \\
$\begin{array}{l}\text { In some months, the women } \\
\text { give money to their } \\
\text { daughters to buy pads but in } \\
\text { most cases, they use cloths. }\end{array}$ \\
\hline
\end{tabular}

\section{Reflections of the group at Purnia district}

\section{Table 4- Purnia district}

The discussion was held with community members of Kasba block, Purnia district of the state of Bihar. There were 20 women in 15-49 years age group and 5 women of climacteric age during the discussion. The block coordinator of Jeevika had organized the meeting. All of them were with Jeevika since last 6years. The reflections of the group on MHM is given below under separate headings. The reflections are mentioned below in separate headings in the table given below. Ms. Shagun of NGO Vatsalya, who is also a co-author of the current article moderated the discussion. $(\mathrm{N}=25)$

\begin{tabular}{|c|c|c|}
\hline Thematic area of MHM & Number of participants & Qualitative data \\
\hline Myths and Misconceptions & 20 & $\begin{array}{l}\text { No mother had told her } \\
\text { daughter to use pads or } \\
\text { informed about menstrual } \\
\text { cycle to their daughters. } \\
\text { When they were girls, they } \\
\text { also learnt from others. } \\
\text { Religious activities are not } \\
\text { done during the MC days } \\
\text { and they do not prepare food } \\
\text { also. Do not touch } \\
\text { vegetables or produce from } \\
\text { fields. }\end{array}$ \\
\hline Menarche & 20 & $\begin{array}{l}\text { MC was considered to be a } \\
\text { disease when they had their } \\
\text { menarche. }\end{array}$ \\
\hline $\begin{array}{l}\text { Use of menstrual materials } \\
\& \text { practices }\end{array}$ & 20 & $\begin{array}{l}\text { No one informs their } \\
\text { daughter before the } \\
\text { menarche. } \\
\text { They corrected the practices } \\
\text { after joining Jeevika. }\end{array}$ \\
\hline
\end{tabular}




\begin{tabular}{|c|c|c|}
\hline Support of family members & 20 & $\begin{array}{l}\text { None of the women had } \\
\text { talked about MHM to their } \\
\text { husbands. } \\
\text { They purchase pads from a } \\
\text { shop on their own near by } \\
\text { the village. } \\
\text { Sometimes as mothers they } \\
\text { buy pads for their daughters } \\
\text { from the market. }\end{array}$ \\
\hline Knowledge on menstruation & 17 & $\begin{array}{l}\text { Dirty blood comes out } \\
\text { during MC. } \\
\text { No group discussions take } \\
\text { place on MC among } \\
\text { members. } \\
\text { Women agreed that they } \\
\text { need to know and talk about } \\
\text { MC. } \\
\text { As members they had } \\
\text { received no training on } \\
\text { MHM. } \\
\text { The members informed that } \\
\text { they can use Meena Manch } \\
\text { platforms to discuss on MC } \\
\text { for their daughters. } \\
\text { As Jeevika members, they } \\
\text { told about Kishori Sakhi } \\
\text { program for 10-18 years old } \\
\text { girls. Issues are discussed in } \\
\text { group on Sundays in a } \\
\text { meeting in the village. The } \\
\text { program is only operational } \\
\text { in Jalalgarh and Kasba block } \\
\text { of Purnia district with the } \\
\text { support of Swabhiman } \\
\text { project of UNICEF. }\end{array}$ \\
\hline Seeking care & 5 & $\begin{array}{l}\text { Few in the group mentioned } \\
\text { about seeking care as } \\
\text { circumstances did not allow } \\
\text { them to do so. }\end{array}$ \\
\hline Health problems & 7 & $\begin{array}{l}\text { Some members take leave } \\
\text { during their MC days as the } \\
\text { MC period is painful and } \\
\text { they do not attend meetings. }\end{array}$ \\
\hline Effects of poor MHM & 20 & $\begin{array}{l}\text { The bathroom in the } \\
\text { common places has dustbins }\end{array}$ \\
\hline
\end{tabular}




\begin{tabular}{|c|c|c|}
\hline & & $\begin{array}{l}\text { but are not usable. Because } \\
\text { of this practice, they leave } \\
\text { work place. }\end{array}$ \\
\hline $\begin{array}{l}\text { Availability \& feasibility of } \\
\text { materials }\end{array}$ & 25 & $\begin{array}{l}\text { Two years ago, in } 16 \text { and } 17 \text {, } \\
\text { they got pads from ASHAs } \\
\text { for Rs } 20 / \text { - for a pack of } 7 \\
\text { pads when the scheme was } \\
\text { in place. } \\
\text { Most of them do not involve } \\
\text { any males to buy pads for } \\
\text { them and only some HHs } \\
\text { do. } \\
\text { They do not prepare for any } \\
\text { menstrual cloth to be used } \\
\text { and use whatever is } \\
\text { available. }\end{array}$ \\
\hline $\begin{array}{l}\text { Disposal of used menstrual } \\
\text { materials }\end{array}$ & 25 & They bury the used pads \\
\hline $\begin{array}{l}\text { Mukhya Mantri Kanya } \\
\text { Utthan Yojana (Chief } \\
\text { Minister Girl Upliftment } \\
\text { Program) }\end{array}$ & 20 & $\begin{array}{l}\text { The mothers in the group } \\
\text { had no idea about the funds } \\
\text { that are transferred in the } \\
\text { account for buying pads for } \\
\text { their school going daughters. } \\
\text { They replied that they had } \\
\text { not received the money. } \\
\text { The teachers informed them } \\
\text { that the money is for health } \\
\text { purposes. } \\
\text { The ANM told them about } \\
\text { the purpose of the money. } \\
\text { The mothers do not go to } \\
\text { school to inquire about the } \\
\text { money. } \\
\text { They replied that some of } \\
\text { the girls used the money on } \\
\text { their own for different } \\
\text { purposes. }\end{array}$ \\
\hline Role of CSOs like Jeevika & 25 & $\begin{array}{l}\text { The group is keen to use } \\
\text { home-made pads and are } \\
\text { keen to make the pads as } \\
\text { well through social } \\
\text { marketing. } \\
\text { The members are also }\end{array}$ \\
\hline
\end{tabular}




\begin{tabular}{|l|l|l|}
\hline & & $\begin{array}{l}\text { interested to buy the pads } \\
\text { from any local source. They } \\
\text { are also keen to sell. }\end{array}$ \\
\hline Suggestions & 25 & $\begin{array}{l}\text { One session on MC per } \\
\text { quarter to be held in the } \\
\text { meetings. } \\
\text { Topics on increasing male } \\
\text { involvement in MHM to be } \\
\text { discussed. }\end{array}$ \\
\hline
\end{tabular}

\section{Results \& Discussions}

The qualitative data of the three districts through the reflections in the groups show that across the three districts, myths \& misconceptions exist among women. Their knowledge on menstruation is very poor \& the myths are deep rooted in their religious \& cultural aspects of life. All these aspects are substantiated academically at global, national \& state level through various studies. As MHM is related to sanitation of the individual \& community as well, the theories of toilet insecurity \& poor support from all the related stakeholders especially for the adult females contributes to poor MHM practices perennially. Among the entire year, the monsoons are the most difficult times for women of the state of Bihar. This aspect is also attributed in an academic study done in the state of Assam which also suffers from inundations every year like Bihar. The concept of sanitation stacking in a study of the current article only entails the practice of open defaecation in Bihar there by making MHM further difficult.Seeking care \& addressing health problems during MHM is also a critical area that needs focus. The socio-cultural rooted obstacles in
MHM are not addressed there by contributing to poor behaviour in seeking care to address health problems. The discussions also brought out the poor practice of using materials while the everpresent issues of availability, feasibility \& access of materials of MHM becomes a huge obstacle in the process of roll out of MHM.The practices of MHM \& the poor quality of the menstrual materials further aggravates the poor sanitation related to MHM leading to health problems in menstruators as replied by the respondents. The availability of sanitary pads by outreach workers \& the Jan Ausadhi Kendras needs to be enhanced at a large scale to ensure its benefit reaches all intended participants especially the women folks. Needless to say, the state has to go miles before addressing the issue of disposal of used menstrual materials as the current method is simply dumping.

The issues of MMKUY again reflects the poor roll out of the program. The responses clearly reflect that huge communication gaps exist between the stakeholders of the program. The program has a dual function \& a dual objective. As the roll out of the program is 
poor, the effects of poor MHM leads to drop-out at work places \& all other multiple obstacles in the MHM way that are difficult to get rid of since these are embedded in the socio-cultural milieu.

The suggestion of the group aims at increasing role of CSOs like Jeevika \& family members to support the women at homes \& work places. The horrific \& painful experiences told by the women during their menarche 20-30 years ago is because of the factor of poor support. Here, the education materials developed on MHM by WSSCC can be handy. These materials can be used by CSOs like Jeevika \& outreach workers like ASHA, AWW, ANM \& other facilitators to orient women \& family members on MHM.

\section{Conclusions}

MHM is both an individual \& community level issue. One can address the first two words of MHM but for the third word, the community has to step in as management is beyond the scope of the individual.

One only hopes that the MHM guideline of Bihar that has encompassed all the modalities as brought out in the study through the response of the stakeholders is rolled out as envisaged. The social infrastructures at community level can be used as facilities for building capacity of various stakeholders.

\section{Acknowledgement}

The lead author acknowledges the role of the NGO Vatsalya of Lucknow \& its chief functionary Dr. Neelam Singh for making him a part of the study. The study was a process in the development of MHM guidelines for the state of Bihar where Vatsalya was the NGO hired by UNICEF Bihar towards the development of MHM guidelines in consultation with various stakeholders. The lead author was a consultant for Vatsalya in the study. The data mentioned in the study was elicited during the consultancy.

\section{Conflict of interest}

Nil

\section{Funding}

Nil for the article

\section{References}

1. Gol, MHFW, https://nhm.gov.in/index 1.php, 2014

2. Wikipedia,

https://en.wikipedia.org/wiki/Me nstrual_Hygiene_Day, 2014.

3. Femme International, https://www.femmeinternationa l.org/the-history-of-the-sanitary$\mathrm{pad} /$.

4. Kaur $\mathrm{R}$ et.al, Menstrual Hygiene Management \& Waste Disposal: Practices \& Challenges faced by Girls/ Women of Developing Countries, Journal of Environmental \& Public Health, 2018: 1730964.

5. Water Aid, Is Menstrual Hygiene \& Management an Issue for Adolescent Girls? Water Aid in South Asia Publication, 2009. 
6. Dasra, Spot on- improving menstrual health \& hygiene in India, 2014.

7. Pratham (2019), Annual Status of Education Report (Rural), 2018.

8. Water Supply \& Sanitation Collaborative Council (WSSCC), Celebrating Womanhood, 2013.

9. ICMR, Annual Report, 2005-06: http://www.icmr.nic.in/annual/2 005-06/hads/rh.pdf.

10.A C Nielsen \& Plan India, Sanitation Protection: Every Woman's Health Right, 2010.

11.NSSO, National Sample Survey Office/Census, 2012.

12. https://menstrual hygiene day.org/wpcontent/uploads/2016/04/indiafactsheet-2015.pdf.

13. International Institute for Population Sciences (IIPS) \& ICF.2017, National Family Health Survey (NFHS-4), India, 2015-16: Mumbai: IIPS.

14.WHO/UNICEF (2012), Joint Monitoring Program (JMP) for Drinking water, sanitation, hygiene. consultation on draft long list of goal, target \& indicator options for future global monitoring of water, sanitationshttps://washdata.org /sites/default/files/documents/r eports/2017-06/JMP-2012post2015-consultation-pdf.

15. World Bank, Menstrual Hygiene Management enables women \& girls to reach their full potential, feature story, $25^{\text {th }}$ May 2018.

https//: worldbank.org/en/news/feature /2018/05/25/menstrual-hygienemanagement.

16. UNICEF, guidance on menstrual health hygiene, https://www.unicef.org/wash/fil es/UNICEF-guidance-menstrualhealth-hygiene-2019.pdf.

17. Global Partnership for Education (GPE) strategic plan, 2020. https://www.globalpartnership.o rg/content/gpe-2020-strategicplan.

18. United Nations, Sustainable Development Goals, 2015. https://www.un.org/sustainable development/sustainabledevelopment-goals.

19.IDF, UNICEF, Menstrual Health \& Hygiene Management, 2013. www.idfngo.org.

20. GoBihar, Free sanitary pads for middle \& high schools of Bihar.https://www.downtoearth. org.in/news/free-sanitary-padsfor-girls-in-middle-and-highschools-of-bihar-44635.

21. Gol, MHM National guidelines, 2015.

https://mdws.gov.in/sites/defaul t/files/menstrual\%20hygiene\%20 management\%20\%20guidelines.pdf.

22. Muralidharan A et.al, unpacking the policy landscape for MHM:implications for school WASH programmes in India.waterlines34(1)79-91.

23. WSSCC, Menstrual Wheel, 2013: wsscc.org/resourcesfeed/menstrual-wheel/.

24.WSSCC, as we grow up flip book, 2013: 
wsscc.org/resources-feed/aswe-grow-up-flipbook/.

25. O' Reilly.K, from toilet insecurity to toilet security: creating safe sanitation for women \& girls. wires water, 2016, 3(1), 19-24. https://doi.org/10.1002/wat2.112 2.

26. Jewitt $S$ et.al, sanitation sustainability, seasonality \& stacking: improved 7 facilities for how long, where \& whom? Geographical journal, 2018, 114.

https://doi.org/10.1111/geoj.122 58.

27.WSSCC, MHM TOT manual: http://wsscc.org/resources-

feed/training-of-trainersmanualwash-and-health-for-menstrualhygienemanagement/.

28. UNICEF, supporting the rights of girls \& women through MHM in the Asia Pacific Region. Realities, progress

opportunities.

http://menstrualhygieneday.org /supporting rights-girls-womenmenstrual-hygiene-

management-mhm-east-asiapacific-region/.

29. GoBihar, NHM, 2019, Sujalswachhsangraha.gov.in/sites/de fault/files/Bihar-MHM-guidelines2019.pdf.

30. Caruso BA et.al, understanding \& defining sanitation insecurity: women's gendered experiences of urination, defaecation \& menstruation in rural Odisha, 2018, India. BMJ glob health, 2017: e000414.
31. Jewitt S, Ryley H, it's a girl thing: menstruation, school attendance, spatial mobility \& wider gender inequalities in Kenya, Geoforum, 56.137147,2014 .

32. Jewitt $S$ \& Ryley $H$, gendered priorities for improved sanitation: insights from Kisum Kenya. Proceedings of the $38^{\text {th }}$ WEDC international conference on water, sanitation \& hygiene services beyond 2015: improving access \& sustainability, Loughborough university, UK, July 2015.

33. JMP, JMP green paper: global monitoring of water, sanitation \& hygiene post-2015.

http://www.wssinfo.org/filead min/user-upload/resources/jmpgreen-paper-15-oct-2015.pdf.

34. Nightingale AJ, Bounding difference: intersectionality \& the material production of gender, caste, class \& environment in Nepal, Geoforum 42, 2011 , 153-162.

35.Ten, VTA, menstrual hygiene, a neglected condition for the achievement of MDGs, 2007. http://www.eepa.be/wcn/dmd ocuments/bgpaper-menstrualhygiene.pdf.

36.Sommer $M$ et.al, A time for global action: addressing girls menstrual hygiene management needs in schools. PLOS medicine, 2016, 13(2): e1001962.

37.Sommer $M$ et.al, where the education system \& women's bodies collide: the social \& 
health impact of girl's experience of menstruation \& schooling in Tanzania, 2010. Journal of adolescence 33(4), 521-529.

38. WHO, annexure 2: safely managed sanitation services \& hygiene, 2017.

http://www.who.int/watersanitation-

health/monitoring/coverage/in dicator-6-2-1-safely-managedsanitation-services-andhygiene.pdf? $\cup \mathrm{a}=1$.

39. Gol, MOEFCC, Notification dated $8^{\text {th }}$ April, 2016. Bbmp.gov.in/documents/10180/ 1920333/SWM-rules-2016.pdf.

40. Peal A J et.al, Hygiene \& Sanitation Software: An Overview of approaches, WSSCC, 2010.

41. Tilley $\mathrm{E}$ et.al, Sanitation in Developing Countries: a review through a gender lens, Journal of WASH for Development, 2013, 4 (2), 248-256.
42. Jenkins $M$ \& Sudgens $S$, Rethinking Sanitation: Lessons \& Innovation for Sustainability \& Success in the New Millenium, Human Development Report office, occasional paper for the HDR 2006 (2006/27), UNDP \& LSHTM, London, UK.

43. Progress on household drinking water, sanitation, hygiene, 20002017, Special focus on inequalities, New York, UNICEF \& WHO, 2019.

44. Gol, Ministry of Planning, List of Aspirational Districts, 2018. https;//niti.gov.in/sites/default/fil es/2018-12/FirstDeltaRankingMay2018-

AspirationalRanking.pdf.

45. Panda Rukmini, Oxfam India, Gender Justice, Let's talk about periods.

https://www.oxfamindia.org/blo g/it-raja-festival-lets-talk-aboutperiods. 